\title{
The Effect of Low-dose X-ray Irradiation on the Quality of Fresh-cut Asparagus in Microwaveable Vacuum Skin Packs
}

\author{
Joongmin Shin ${ }^{1}$ \\ Engineering and Technology Department, University of Wisconsin-Stout, \\ Menomonie, WI 54751
}

\section{Bruce Harte}

School of Packaging, Michigan State University, East Lansing, MI 488241223

\section{Janice Harte}

Department of Food Science and Human Nutrition, Michigan State University, East Lansing, MI 48824

Kirk Dolan

Department of Food Science and Human Nutrition, Michigan State University, East Lansing, MI 48824; and the Department of Biosystems and Agricultural Engineering, Michigan State University, East Lansing, MI 48824

Additional index words. asparagus, vacuum skin packaging, irradiation, $\mathrm{x}$-ray, phenylalanine ammonia-lyase

\begin{abstract}
Low-dose x-ray irradiation was used on vacuum skin-packaged fresh-cut asparagus to extend its shelf life and improve its microbial safety. Freshly imported Peruvian asparagus (Asparagus officinalis L.) spears were obtained from a local source, cleaned, trimmed, and sanitized and then vacuum skin-packaged (VSP) in a tray pack system. A breathable lid film was vacuum-sealed to protect the product from contamination and allow for gas exchange. Asparagus were packaged in VSP, which modified the package atmosphere, and exposed to a target dose of $1.0 \mathrm{kGy}$ or left untreated. Asparagus were also placed in low-density polyethylene (LDPE) bags as a control. All samples were then stored at $4{ }^{\circ} \mathrm{C}$ for 24 days. To determine the effectiveness of the irradiation treatment, sample packages were periodically removed from storage and several measurements were used to evaluate the product, including headspace gas content, microbial growth, water soluble sugar content, and enzyme activity. A dose of $1.0 \mathrm{kGy}$ reduced initial microbial population up to $3.8 \mathrm{log}$ colony-forming units (cfu)/g and maintained $20 \%$ more of the initial sugar content relative to the non-irradiated VSP asparagus. Phenylalanine ammonia-lyase (PAL) activity in VSP asparagus was lower than in the control package (LDPE bag) regardless of irradiation treatment $(P<0.05)$. However, $x$-ray treatment increased the PAL activity of asparagus in VSP up to Day $8(P<0.05)$.
\end{abstract}

Fresh-cut fruit and vegetable consumption has rapidly increased in the United States over the last decade. Currently, almost $30 \mathrm{~kg} /$ person of minimally processed fruits and vegetables are consumed per year in the United States (Abadias et al., 2008). Fresh-cut products are gaining in popularity as a result of consumer demand for convenience and nutri-

\footnotetext{
Received for publication 18 June 2010. Accepted for publication 30 Oct. 2010.

Joongmin Shin thanks Dr. Sanghyup Jeong at Michigan State University for his help with the irradiation treatment and thanks to Myra Hughes Foster at Cryovac (Duncan, SC) for supplying the VSP trays and films.

${ }^{1}$ To whom reprint requests should be addressed; e-mailshinj@uwstout.edu.
}

tion. Fresh green asparagus (Asparagus officinalis L.) is one of the most popular minimally processed vegetables in the United States as a result of its wealth of fiber and essential nutrients (Sothornvit and Kiatchanapaibul, 2009; Villanueva et al., 2005). However, it has a very limited shelf life because of its high respiration rate, rapid moisture loss, and microbial susceptibility (Simon et al., 2004). Minimally processed fresh-cut asparagus has relatively high initial microbial counts $\left(10^{4}\right.$ to $10^{6} \mathrm{cfu} / \mathrm{g}$ ) (Garcia-Villanova et al., 1987; Simon et al., 2004). Therefore, it may be necessary to further treat fresh-cut asparagus before delivery to the consumer to reduce the microbial population. Various methods can be used to reduce microbial populations, including use of sanitizers and irradiation. Chlorine compounds are the most popular group of
Food and Drug Administration-approved sanitizers in the food industry but have limited effectiveness because of their rapid inactivation as a result of interaction with organic matter and difficulty in reaching into tissue crevices (Fan et al., 2003).

Ionizing radiation can enhance the safety and lengthen the shelf life of fresh-cut fruits and vegetables. Minimal product damage occurs because product temperature does not increase, and it is easily accomplished after packaging so that no recontamination of the product takes place (Farkas et al., 1997). The Food and Drug Administration (FDA) has approved ionizing radiation dose of up to 1.0 $\mathrm{kGy}$ for general fresh fruits and vegetables to control insects and to extend shelf life (FDA, 2009; Olson, 1998). Low-dose ionizing irradiation effectively reduces microbial populations on many fresh products and can extend product shelf life. Schmidt (2004) used 0.70 and $0.95 \mathrm{kGy}$ irradiation to reduce the microbial population on fresh-cut tomatoes and obtained 1.8 and $2.2 \log \mathrm{cfu} / \mathrm{g}$ reductions. Farkas (2006) showed that $1.0 \mathrm{kGy}$ irradiation significantly reduced food spoilage bacteria and extended the sensorial quality of fresh-cut peppers and carrots. Hagenmaier and Baker (1997) found that chlorine sanitization in combination with $\mathrm{x}$-ray irradiation $(0.15$ to $0.50 \mathrm{kGy})$ reduced the microbial contamination on lettuce.

The enzyme activity of fresh-cut products can be affected by irradiation. Specially, PAL activity is important because PAL is the main enzyme that causes the development of lignification and toughness (An et al., 2007; Powers and Drake, 2006; Waldron and Selvendran, 1990). Therefore, some studies showed that PAL response is closely correlated to decreased shelf life and visual quality of asparagus (Hennion et al., 1992; Howard et al., 1995). However, there are not many studies about PAL activity on asparagus after irradiation treatment. Previous research with lettuce (Fan et al., 2003), mushrooms (Benoit et al., 2000), and Clementines (Oufedjikh et al., 2000) have shown increased PAL activity after irradiation treatment. On the other hand, some enzyme activities were inhibited using irradiation. El Assi et al. (1997) determined that polygalactouronase activity was irreversibly suppressed but pectin methylesterase was significantly increased in tomato and pericarp after irradiation. Gautam et al. (1998) also reported reduction of polyphenol oxidase activity by irradiation at 0.5 and $1.0 \mathrm{kGy}$ on mushrooms.

$\mathrm{X}$-ray irradiation is the newest in ionizing irradiation technologies that is commercially used for foods. It is high-energy photons produced by the interaction of charged particles with matter, and it has essentially the same properties as gamma ray. However, $\mathrm{x}$-ray is produced by a high-energy beam, which is generated from machine, whereas gamma ray is originated from radioisotopes (Farkas, 2006). It is generally lower in energy and therefore less penetrating than gamma ray (Environmental Protection Agency, 2007). Machine-generated x-ray can offer greater 
flexibility. For instance, it can be turned on and off unlike the constant emission of gamma ray from radioisotopes. Also, the x-ray generation does not involve radioactive substance and is free from harmful radioactive waste handling or disposal issue. On the other side, Robertson et al. (2006) said that x-ray irradiation has less negative consumer perception than gamma irradiation because consumers are familiar with medical x-ray.

Vacuum skin packaging is an advanced packaging technique and is used to maintain the quality of fresh meat and dairy products (Nychas and Tassou, 1996). The product is placed into a tray and film is brought into contact with the lid area. Rapid heating of the lid film at high temperature then takes place, and the thermally softened plastic is drawn over the product surface to form a "skin" over the product. Some lid films for VSP have high $\mathrm{CO} / \mathrm{CO}_{2}$ permeability and control the respiration rate of fresh vegetables, similar to what occurs with modified atmosphere packaging systems (Phillips, 1996). Vazquez et al. (2004) reported that the surface heat treatment during the packaging process slows bacterial growth more than traditional vacuum packaging. The combination with VSP with irradiation has the potential to maintain the quality of the asparagus. Thus, the objective of this research was to determine the effect of low-dose x-ray irradiation treatment on Peru asparagus. Microbial populations, PAL activity, and sugar content in the asparagus were monitored during $24 \mathrm{~d}$ of storage.

\section{Materials and Methods}

\section{Materials}

Asparagus and packaging. Untreated raw asparagus spears, imported from Peru, were purchased from a local grocery store (East Lansing, MI). Low density polyethylene bags $(152.4 \mathrm{~mm} \times 304.8 \mathrm{~mm} \times 0.038 \mathrm{~mm})$ were purchased from a local grocery store. Microwavable multilayer barrier trays (Simple Steps $^{\mathrm{TM}} ; 114.3 \mathrm{~mm} \times 171.45 \mathrm{~mm} \times 0.03175$ $\mathrm{mm}$ ) and a microwavable lidding film (VP306K) were obtained from Cryovac (Duncan, SC). The oxygen transmission rate and carbon dioxide transmission rate of the film were $1.6 \times$ $10^{-6} \mathrm{~mol} / \mathrm{m}^{2} / \mathrm{s}\left(3024 \mathrm{~cm}^{3} / \mathrm{m}^{2} / \mathrm{d}\right)$ and $2.9 \times 10^{-6}$ $\mathrm{mol} / \mathrm{m}^{2} / \mathrm{s}\left(5523 \mathrm{~cm}^{3} / \mathrm{m}^{2} / \mathrm{d}\right)$, respectively. A sanitizer containing chlorine as the a.i. (Johnson CRS Fruits \& Vegetable Wash) was purchased from S.C. Johnson (Sturtevant, WI).

\section{Methods}

Sample preparation. Asparagus spears without any visual defect were sorted to $\approx 8.5$ $\mathrm{mm}$ in diameter and cut into $\approx 152.4-\mathrm{mm}$ lengths using a stainless steel knife. Spears were washed with distilled water to remove soil and any contaminant, immersed in sanitizer solution, containing $200 \mathrm{ppm}$ of chlorine, and rinsed twice with distilled water. The treatments were divided into three groups: 1) control (CON); 2) VSP (VSP); and 3) VSP plus x-ray irradiation (I-VSP). For CON, $210 \mathrm{~g}(\approx 18$ asparagus $)$ of fresh-cut asparagus were placed in LDPE bags, which are commonly used for fresh fruits and vegetables in retail stores. The bags were not sealed to provide ambient air during the storage. For VSP samples, $210 \mathrm{~g}$ of fresh-cut asparagus was transferred under sanitary conditions into the trays and sealed using the Multivac T-200 tray sealer in VSP mode (Multivac, Kansas City, $\mathrm{MO})$. The heat sealer temperature was 140 ${ }^{\circ} \mathrm{C}$, the duration of heating was $2.5 \mathrm{~s}$, and vacuum pressure was $91 \mathrm{kpa}$ (910 mbar) for $1 \mathrm{~s}$. All packaged samples were stored at $4{ }^{\circ} \mathrm{C}$ for $24 \mathrm{~d}$.

Irradiation treatment. A low-energy x-ray food irradiator (Rayfresh Foods, Ann Arbor, MI) was used to irradiate the vacuum-packaged asparagus. Each packaged VSP was manually inserted into the irradiation chamber $(420 \mathrm{~mm} \times 420.75 \mathrm{~mm} \times 550 \mathrm{~mm})$ and irradiated. The irradiator operating condition was $145 \mathrm{KV}$ with $19 \mathrm{~mA}$, and the achieved rate of dosage was $1.0 \mathrm{kGy} / 30 \mathrm{~min}$. For a preliminary test to determine the irradiation disinfectant effectiveness, VSP trays containing asparagus were irradiated at five different dose levels $(0,0.5,0.8,1.0$, and $1.8 \mathrm{kGy})$. Based on the results of these tests, a dosage of $1.0 \mathrm{kGy}$ was selected for all the irradiated samples (I-VSP), which were put into storage $\left(4{ }^{\circ} \mathrm{C}\right)$. Each package was placed individually into the irradiation chamber and exposed to the x-rays. As a result of the characteristic pattern of x-rays and the irregular shape of the asparagus, the actual dose gradient was substantial in the sample. To help obtain a uniform irradiation treatment, all trays were treated twice (top and bottom side). Calculations for time of $\mathrm{x}$-ray exposure were based on the maximum time to achieve the desired dose rate. Calibration was achieved by placing radiochromic dosimeters (Rayfresh Foods) on both top and bottom sides of the sample. For samples placed into storage, the target dose was $1.0 \mathrm{kGy}$, and the actual dose was $0.94 \pm$ $0.075 \mathrm{kGy}$ as a result of spatial variability. Three replications were performed $(n=3)$.

Gas analysis. The $\mathrm{O}_{2}$ and $\mathrm{CO}_{2}$ concentrations within the trays were monitored using an Illinois 6600 Head Space Analyzer (Illinois Instruments, Johnsburg, IL). A syringe needle was carefully inserted into the tiny gaps between the asparagus spears to extract headspace $(10 \mathrm{~mL})$ from the VSP packages and the headspace gas was injected into the instrument. A rubber septum was placed onto the lidding film to avoid gas exchange with the surrounding atmosphere during headspace gas extraction. Three samples were used for replication $(\mathrm{n}=3)$.

Microbial analysis. Twenty-five grams of asparagus (approximately two whole asparagus spears) were aseptically removed from the trays, weighed, and homogenized in a stomacher bag (Whirl-Pack ${ }^{\mathrm{TM}}$; Nasco, Atkinson, WI) for $2 \mathrm{~min}$ with $225 \mathrm{~mL}$ of sterile peptone water. One milliliter of the asparagus/fluid mixture was removed and diluted in sterile tubes containing $9 \mathrm{~mL}$ of $0.1 \%$ peptone water to make serial dilutions $\left(10^{-1}\right.$ to $\left.10^{-5}\right)$. The appropriate dilutions were plated on growth medium. Total aerobic bacteria (TPC) were determined on trypticase soy agar (Difco,
Detroit, MI) containing $0.6 \%$ yeast extract with $100 \mathrm{ppm}$ cyclohexamide (Sigma-Aldrich Co., St. Louis, MO). The plates were counted after $72 \mathrm{~h}$ of incubation at $35{ }^{\circ} \mathrm{C}$. Yeasts and Molds were determined on potato dextrose agar (Difco) containing 20 ppm streptomycin (Sigma) and 50 ppm ampicillin (Sigma). After 3 to $5 \mathrm{~d}$ of incubation at room temperature $\left(22{ }^{\circ} \mathrm{C}\right)$, the number of microorganisms was determined. Three samples were used for replication $(\mathrm{n}=3)$.

Determination of sugar content. Three asparagus spears were removed from each package and roughly ground using a blender (Oster 6640; Oster, Boca Raton, FL). Then, $10 \mathrm{~g}$ of the ground sample and $25 \mathrm{~mL}$ of distilled water were mixed and homogenized using another blender (Oster 6640; Oster) for 2 min. The mixture was then centrifuged at $6500 \times \mathrm{g}$ for $20 \mathrm{~min}$ at ambient temperature. The supernatant was filtered through a polytetrafluoroethylene membrane filter $(0.45$ $\mu \mathrm{m})$, and the water-soluble sugar compounds (glucose, sucrose, fructose) were analyzed using a high-performance liquid chromatography (Waters 2695; Waters, Milford, MA) equipped with a refractive index detector (Waters 410; Waters). The mobile phase was made up of $100 \%$ high-performance liquid chromatography grade water with a Rezex RCM-monosaccharide column (Phenomenex, Torrance, CA) and a flow rate of $0.6 \mathrm{~mL} / \mathrm{min}$. The temperature of the column and detector were set at 85 and $40^{\circ} \mathrm{C}$, respectively. All tests were replicated three times $(\mathrm{n}=3)$.

Phenylalanine ammonia-lyase enzyme assay. The PAL enzyme was extracted using the method of Lister et al. (1996). Three frozen asparagus spears were roughly grinded using a blender (Oster 6640; Oster), and $5 \mathrm{~g}$ of the samples was collected and homogenized with $20 \mathrm{~mL}$ of $50 \mathrm{~mm}$ phosphate buffer $(\mathrm{pH} 7.0)$ containing 5\% polyvinylpyrrolidone (molecular weight 44,000), $50 \mathrm{~mm}$ sodium ascorbate, $18 \mathrm{~mm}$ mercaptoethanol, and $0.1 \%$ Triton $\mathrm{X}-100$. The homogenized solution was filtered with cotton gauze and centrifuged at $12,000 \times \mathrm{g}$ for $30 \mathrm{~min}$. During preparation, the temperature was kept at $4{ }^{\circ} \mathrm{C}$. Then, 0.25 $\mathrm{mL}$ of the sample (crude enzyme) was mixed with $0.06 \mathrm{M}$ borate buffer $(\mathrm{pH} 9.5,0.875$ $\mathrm{mL}$ ), and $10 \mathrm{mg}$ of L-phenylalanine was added to the $0.25-\mathrm{mL}$ sample solution (final concentration of $11 \mathrm{~mm}$ ) to initiate the reaction. Sample tubes were then incubated at $30{ }^{\circ} \mathrm{C}$ for $1 \mathrm{~h}$ and $0.125 \mathrm{~mL}$ of trifluoroacetic acid (35\%) added to stop the reaction. The tubes were then centrifuged for $5 \mathrm{~min}$ at $3000 \times \mathrm{g}$ to pelletize the denatured protein. One milliliter of the supernatant was deposited into a $1-\mathrm{cm}$ quartz cuvette, and PAL activity was estimated by measuring the changed absorbance at $290 \mathrm{~nm}$ using a Lambda 21 ultraviolet/visible spectrophotometer (Perkins Elmer, Waltham, MA). The PAL activity was defined as mmol of L-phenylalanine per milligram protein for $1 \mathrm{~h}$ $(\mathrm{mmol} / \mathrm{h} / \mathrm{mg}$ protein). The protein content was estimated using the Bradford method (Bradford, 1976). The binding of Coomassie Brilliant Blue G-250 dye to proteins was detected at $595 \mathrm{~nm}$ and calculated to the 
concentration of protein in the sample solution above using a spectrophotometer (Perkins Elmer). Bovine serum albumin (BSA) was used for a protein standard. The protein assay kit (including reagent and BSA) was purchased from Bio-Rad Laboratories, Inc. (Quick Start ${ }^{\top \mathrm{M}}$ Bradford protein assay; Hercules, CA).

Statistical analysis. Statistical evaluation of the different treatments (CON, VSP, I-VSP) and the different times $(0,4,8,12,16,20,24)$ was performed using analysis of variance. Differences $(P<0.05)$ among means were analyzed with the Tukey's honestly significant difference test. The statistical software used was SPSS Version 13 (SPSS inc., Chicago, IL).

\section{Results and Discussion}

Headspace gas analysis. Samples irradiated at $1.0 \mathrm{kGy}$ had slightly higher $\mathrm{CO}_{2}$ levels than non-irradiated VSP asparagus through $8 \mathrm{~d}$, whereas $\mathrm{O}_{2}$ concentrations of each were statistically similar for the irradiated asparagus (Fig. 1). The differences in $\mathrm{CO}_{2}$ content were greatest on Day 4. Headspace gas concentrations in both packages eventually became steady at $10 \% \mathrm{O}_{2}$ and $7 \% \mathrm{CO}_{2}(\mathrm{CON}$ had ambient air during the storage). Atmospheres in both I-VSP and VSP were within the $\mathrm{CO}_{2}$ and $\mathrm{O}_{2}$ levels sufficient to maintain the quality of fresh asparagus, which achieved steady state at $\approx 10 \% \mathrm{O}_{2}$ and $15 \%$ $\mathrm{CO}_{2}$ (Simon et al., 2004). These results agree with other studies in which fresh produce was treated with ionizing radiation. Han et al. (2004) observed that a $1.5-\mathrm{kGy}$ treatment significantly increased $\mathrm{CO}_{2}$ concentration in romaine lettuce packages $258.2 \%$ higher than the control (non-irradiated) at $0 \mathrm{~d}$. Hagenmaier and Baker (1997) reported that the respiration of irradiated iceberg lettuce increased by $33 \%$ higher than the control. The mechanism responsible for the increased irradiation-induced respiration not well understood. Gunes et al. (2001) postulated that irradiation-stimulated catabolism of acetate may have increased $\mathrm{CO}_{2}$ production.

Microbial analysis. The effect of x-ray irradiation on the growth of microorganisms in VSP asparagus is shown in Figure 2. The initial population of TPC and mold/yeast was reduced significantly by the different radiation levels $(0.5,0.8,1.0$, and $1.8 \mathrm{kGy})$. The highest dose (1.8 kGy) caused the greatest reduction in both TPC and mold/yeast (3.8 and $4.0 \mathrm{log} \mathrm{cfu} / \mathrm{g}$, respectively). As mentioned previously, $1.0 \mathrm{kGy}$ is the maximum allowable to apply to fresh fruits and vegetables for the purpose of disinfestations and maturation delay (FDA, 2009). Thus, 1.0kGy exposure was further characterized in this study. A microbial population profile during storage at $4{ }^{\circ} \mathrm{C}$ for $21 \mathrm{~d}$ is shown in Figure 3. The initial aerobic bacterial counts of the irradiated samples (at 0 d) had a 4-log reduction after $1.0 \mathrm{kGy}$ of $\mathrm{x}$-ray exposure. The imported (Peru) asparagus had relatively high initial bacterial counts of $7.15 \mathrm{log} \mathrm{cfu} / \mathrm{g}$ for TPC and $7.19 \mathrm{log} \mathrm{cfu} / \mathrm{g}$ for yeast/mold on the non-sanitized asparagus. Even after treatment with 200 ppm of a chlorine solution, the
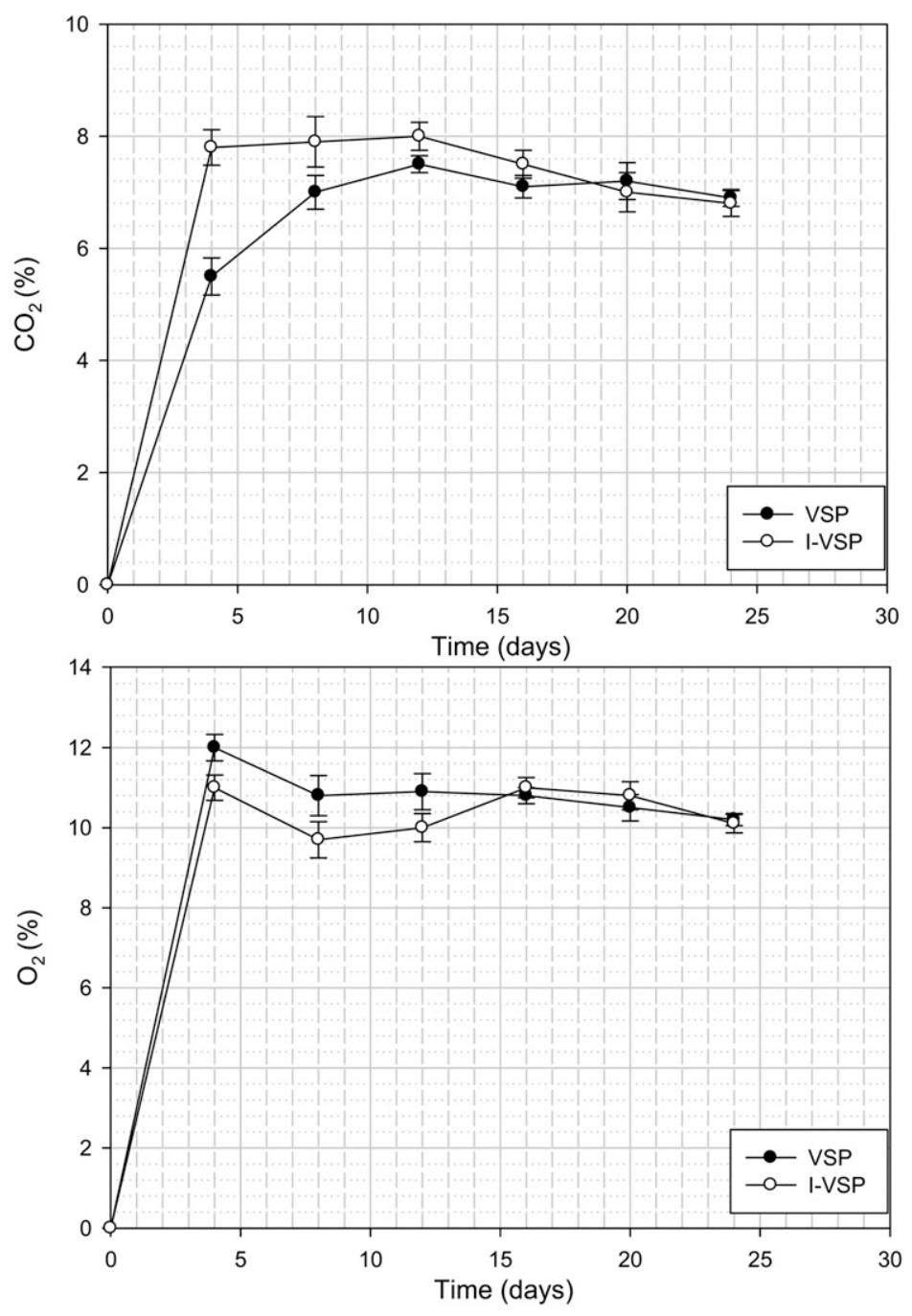

Fig. 1. The percent $\mathrm{CO}_{2}$ and $\mathrm{O}_{2}$ in vacuum skin-packaged (VSP) and VSP plus irradiation (I-VSP) during storage at $4{ }^{\circ} \mathrm{C}$. Irradiation level $=1.0 \mathrm{kGy}$.

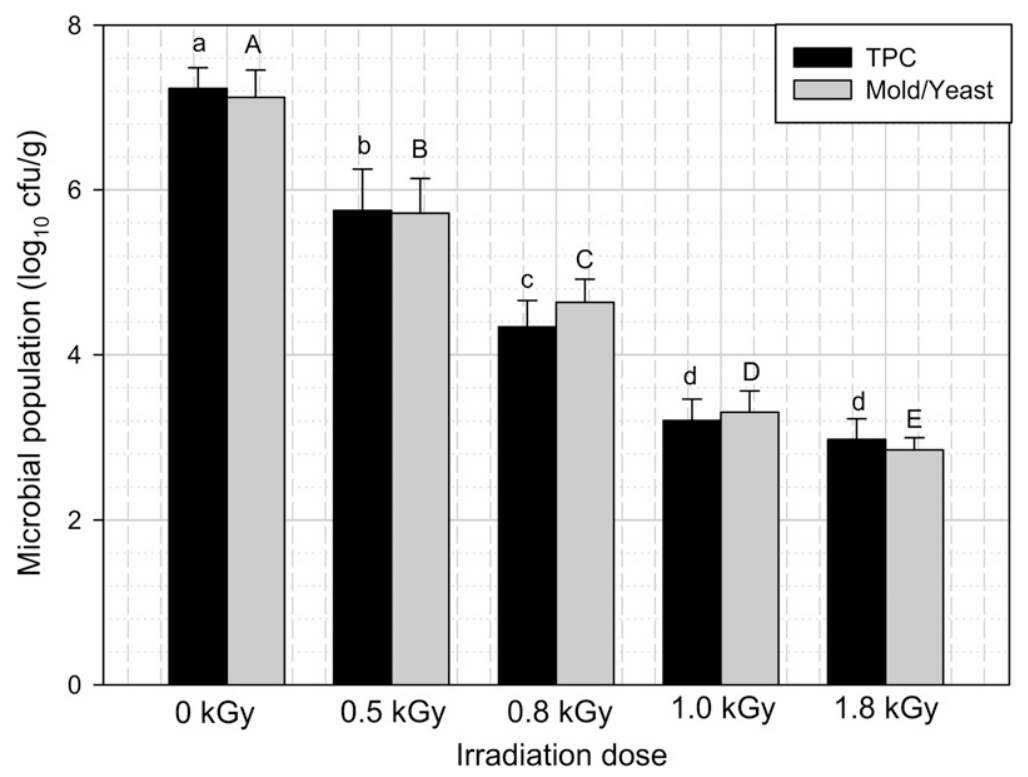

Fig. 2. Effect of irradiation dose on the total plate count (TPC) and mold/yeast count of vacuum skinpackaged asparagus immediately after irradiation. Different letters (a-b for TPC and A-E for mold/ yeast) among irradiation dose indicate significant difference $(P<0.05)$. 

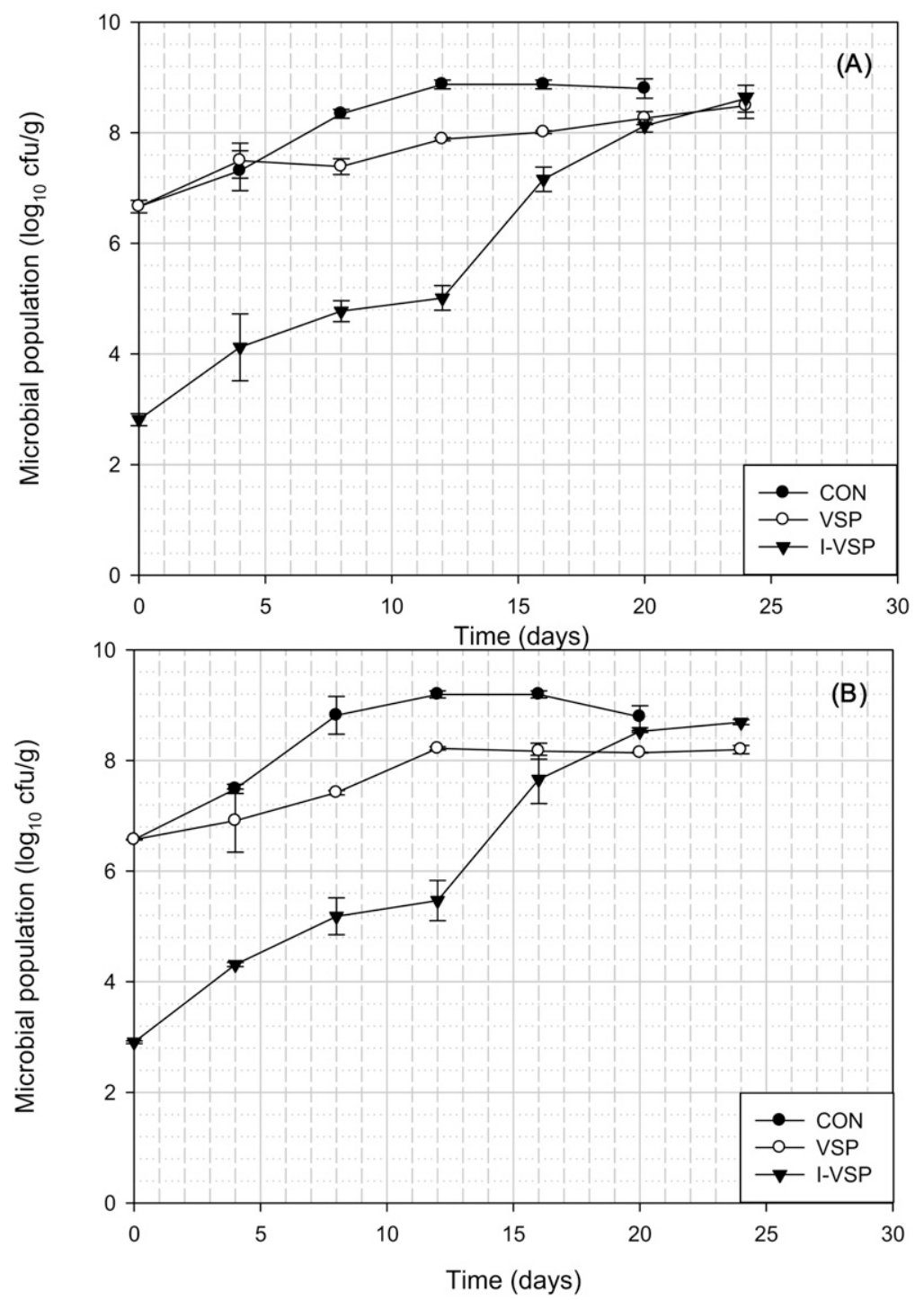

Fig. 3. Microbial counts on asparagus spears at $4{ }^{\circ} \mathrm{C}$ during $24 \mathrm{~d}$ storage (A) total plate count [TPC, initial without sanitization $=7.15 \mathrm{log}$ colony-forming units $(\mathrm{cfu}) / \mathrm{g}] ;(\mathbf{B})$ yeast $/ \mathrm{mold}$ counts (initial without sanitization $=7.19 \mathrm{cfu} / \mathrm{g})$. Irradiation level $=1.0 \mathrm{kGy}$.

reductions were less than one log cycle for each microbial test. TPC was $6.67 \log \mathrm{cfu} / \mathrm{g}$ and mold/yeast was $6.57 \mathrm{log} \mathrm{cfu} / \mathrm{g}$. Thus, the microbiological safety of the asparagus could be a potential health issue because the high initial contamination increases the risk of pathogens presence on the product as well as an impact on the shelf life of the asparagus. $\mathrm{X}$-ray treatment had a significant effect on the reduction of microorganisms. Both the TPC and mold/yeast in the CON sample reached $8.0 \mathrm{log} \mathrm{cfu} / \mathrm{g}$ after $4 \mathrm{~d}$ storage, and significant visual deterioration and odor was detected at $8 \mathrm{~d}$ (observation only). Microbial numbers above $8.0 \mathrm{log} \mathrm{cfu} / \mathrm{g}$ of total bacteria correlate with food spoilage, which will result in the end of shelf life (Garcia-Gimeno et al., 1998). TPC and mold/yeast in VSP also reached levels of $8.0 \mathrm{log} \mathrm{cfu} / \mathrm{g}$ within $16 \mathrm{~d}$. A previous study with locally harvested asparagus reported that VSP maintained its shelf life (including microbial growth and sensory quality) up to $21 \mathrm{~d}$ (Shin et al., 2008). The counts in the imported asparagus may have increased dur- ing transportation and handling depending on temperature and exposure. Results showed that the $1.0-\mathrm{kGy}$ treatment significantly reduced the initial microbial contamination on the asparagus. After the treatment, TPC and mold/yeast were, respectively, 2.81 and 2.91 $\log \mathrm{cfu} / \mathrm{g}$ lower than untreated asparagus.

Change in sugar content. Initial glucose and fructose contents in the asparagus were $2.11 \mathrm{mg} / \mathrm{g}$ for glucose and $4.41 \mathrm{mg} / \mathrm{g}$ for fructose (Fig. 4), and the values corresponded to the range from Krzesinski et al. (2007). As a result of a significant level of decay of the asparagus in CON, glucose and fructose in the package were not measured after Day 16 . The glucose and fructose levels declined most rapidly in CON, less rapidly in the VSP, and least rapidly in the I-VSP. For CON, the glucose reduction was $\approx 77 \%$ (2.11 to 0.50 $\mathrm{mg} / \mathrm{g}$ ) and that of fructose was $30 \%$ (4.41 to $3.05 \mathrm{mg} / \mathrm{g}$ ) during the storage. The total reduction of glucose and fructose in I-VSP was $\approx 28 \%$ (from 2.17 to $1.56 \mathrm{mg} / \mathrm{g}$ ) and $22 \%$ (from 4.92 to $3.85 \mathrm{mg} / \mathrm{g}$ ), respectively. Non- irradiated asparagus (VSP) lost $\approx 48 \%$ ( 2.10 to 1.10$)$ glucose and $42 \%$ (4.41 to $2.54 \mathrm{mg} / \mathrm{g})$ fructose on Day 24. The quantity of sucrose detected in the asparagus was negligible over the storage (the data are not shown). The degree of sugar consumption in fruits and vegetable is closely related to respiration and temperature (Hirai, 1982). Even if I-VSP had higher respiration rate from Day 0 to 8 than VSP, I-VSP maintained higher sugar level during the storage time. Several studies have reported effects on sugar content of other fruits and vegetables treated with gamma irradiation, one of the ionized irradiation. Benkeblia et al. (2004) reported no significant decrease in sugars in onion bulb after $0.39 \mathrm{kGy}$ treatment after 6 months storage at 4 and $10^{\circ} \mathrm{C}$. Fan and Sokorai (2002) reported no significant changes in the nutritional composition of iceberg lettuce subjected to a low dose ( 0.35 to $1.0 \mathrm{kGy})$ of irradiation treatment. Boylston et al. (2002) mentioned that changes in the nutrient composition and overall quality of fresh products after irradiation have frequently occurred at medium and high doses of treatment. The higher glucose and fructose reduction in VSP, relative to I-VSP, may have been caused by the higher microbial growth. Fermentation as a result of microbial growth uses sugar, which decreases its concentration and results in the production of lactic acid (Lamikanra et al., 2000). On the other hand, Chalker-Scott and Fuchigami (1989) observed that irradiation stimulated hydrolysis of reserved polysaccharides such as starches and increased sugar contents in mango and pineapple. The sugar concentration in VSP also maintained higher level than CON. VSP maintained a controlled atmosphere during the storage, and it is considered to delay sugar consumption from respiration and microbial growth.

Changes in phenylalanine ammonia-lyase activity. In the early of storage, PAL activity in CON rapidly increased up to five times higher than VSP on Day 8 (Fig. 5). The irradiation (x-ray) effect on PAL activity was also shown to be statistically significant. The activity in I-VSP was higher $(P<0.05)$ than VSP at Day 8 . Then, PAL activity in I-VSP was decreased and the difference from VSP became negligible. PAL activity presented a peak at Day 8 of storage, but its activities on both VSP and I-VSP were significantly lower than the control group. It indicated that treatment in irradiation and/or vacuum skin packaging inhibited the increase in PAL activity. No information exists on the irradiation effect on PAL activity of asparagus to our knowledge. However, tissue injury and stress resulting from irradiation may increase enzyme synthesis or activity in fresh produce (Chalker-Scott and Fuchigami, 1989). Fan and Sokorai (2005) showed that ionizing radiation increased electrolyte leakage in all vegetables evaluated. Irradiation treatment may cause minor stress to the asparagus, and it may affect its PAL activity. Some studies with other fruits and vegetables have been observed the enhancement of PAL activity by irradiation. Benoit et al. (2000) observed up to four times higher PAL activity in 2.5 kGy-treated 

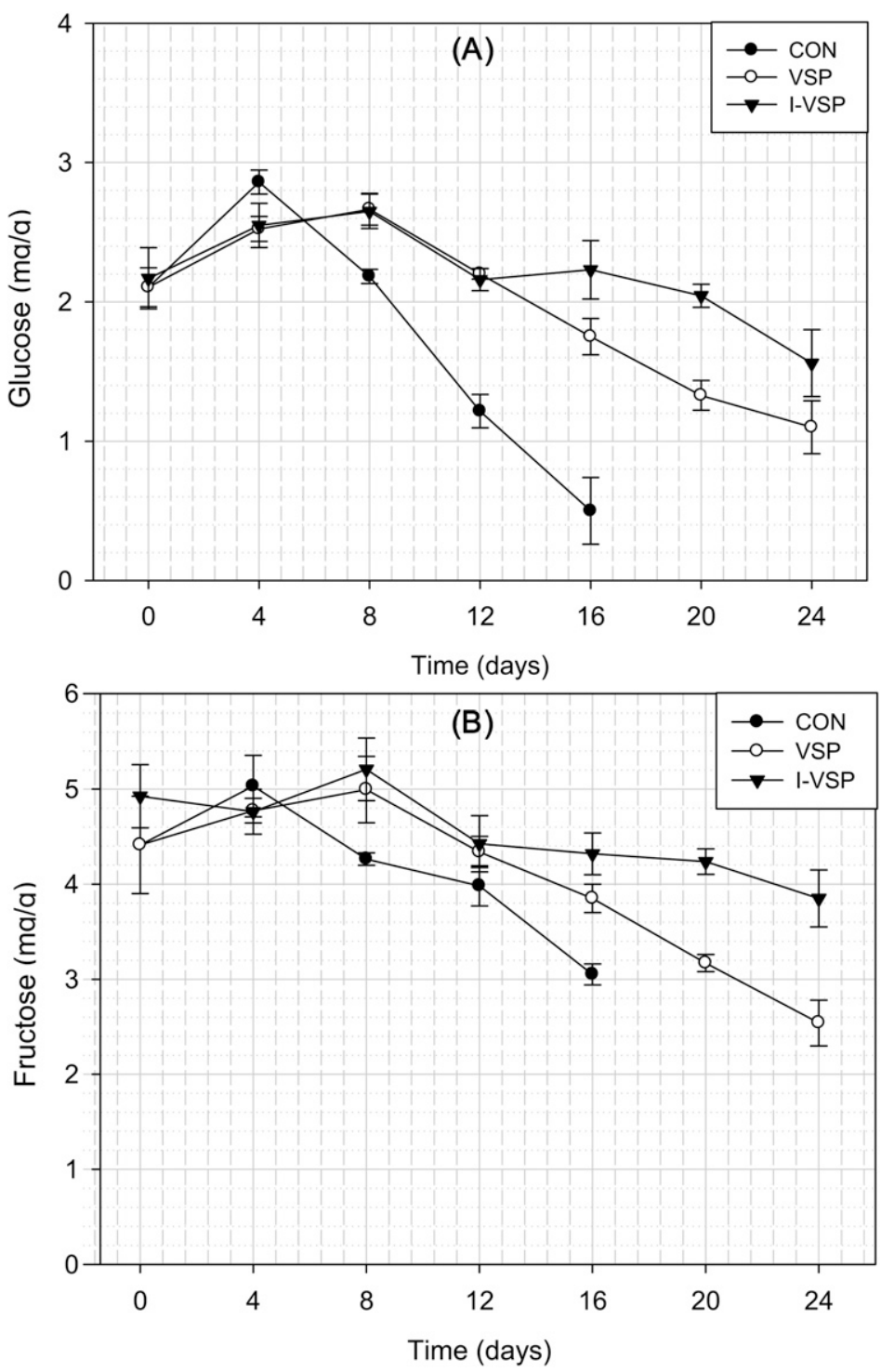

Fig. 4. Sugar content $(\mathrm{mg} / \mathrm{g})$ in asparagus spears stored at $4{ }^{\circ} \mathrm{C}$. $(\mathbf{A})$ Glucose; $(\mathbf{B})$ fructose. Irradiation level $=$ $1.0 \mathrm{kGy}$.

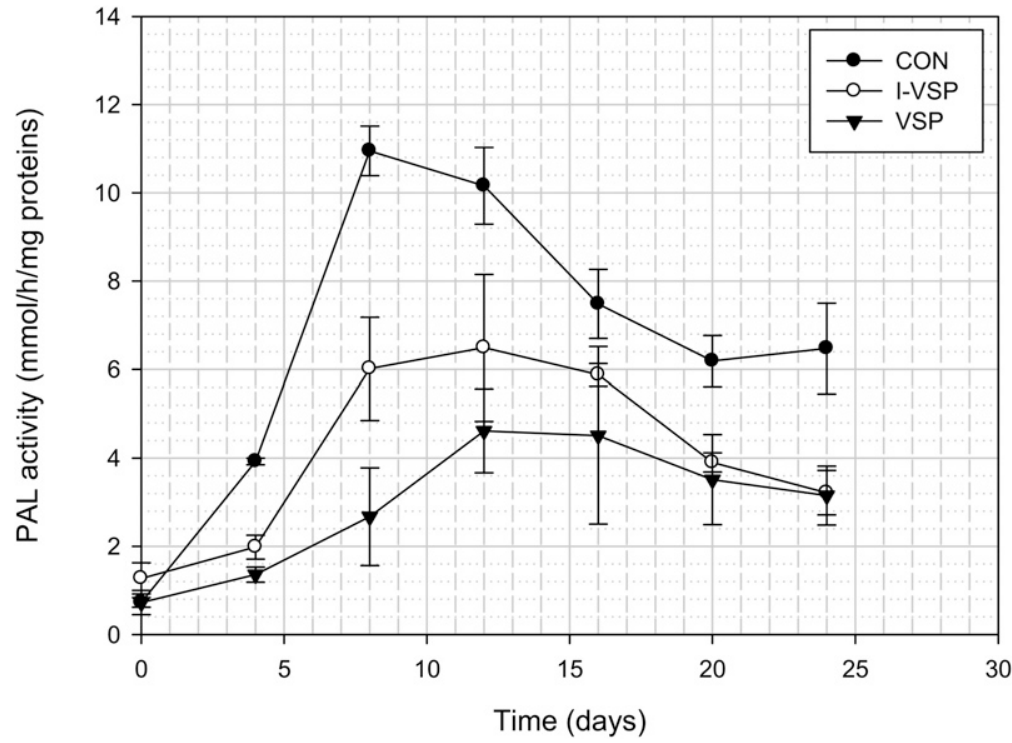

Fig. 5. Phenylalanine ammonia lyase (PAL) activity profile on asparagus during storage at $4{ }^{\circ} \mathrm{C}$. Irradiation level $=1.0 \mathrm{kGy}$. mushrooms than a non-irradiated sample on Day 3. The PAL activities in the mushroom then gradually decreased, and the author postulated this was curing from the minor cell damage. More detailed study on the impact of irradiation on asparagus quality is needed.

\section{Conclusion}

Irradiation treatment reduced aerobic bacteria (TPC) and mold/yeast populations significantly and helped to maintain sugar (glucose and fructose levels) in asparagus. In this study, irradiation temporarily increased PAL activity. Further research should be conducted to determine if this increase affects product attributes such as lignification. A more detailed study, including analytical measurement of texture and fiber content, also needs to be done to evaluate the quality change. $\mathrm{X}$-ray treatment is an effective disinfection process. It will enhance consumer safety by decreasing the number of viable microorganisms on the product. The commercial success of irradiated foods is at least partially dependent on the consumer's perception of product quality. Thus, a thorough examination of the sensory quality and an evaluation of any nutritional changes caused by $\mathrm{x}$-ray treatment are recommended to determine its commercial feasibility.

\section{Literature Cited}

Abadias, M., J. Usall, M. Anguera, C. Solsona, and I. Vinas. 2008. Microbiological quality of fresh, minimally-processed fruit and vegetables, and sprouts from retail establishments. Intl. J. Food Microbiol. 123:121-129.

An, J., M. Zhang, and Q. Lu. 2007. Changes in some quality indexes in fresh-cut asparagus pretreated with aqueous ozone and subsequent modified atmosphere packaging. J. Food Eng. 78:340-344.

Benkeblia, N., S. Onodera, and N. Shiomi. 2004 Effect of gamma irradiation and temperature on fructans (fructo-oligosaccharides) of stored onion bulbs Allum cepa L. Food Chem. 87:377-382.

Benoit, M.A., G.D. Aprano, and M. Lacroix. 2000 Effect of gamma irradiation on phenylalanine Ammonia-lyase activity, total phenolic content, and respiration of Mushrooms (Agaricus bisporus). J. Agr. Food Chem. 48:6312-6316.

Boylston, T.D., C.A. Reitmeier, H.M. James, G.A Mosher, and L. Taladriz. 2002. Sensory quality and nutrient composition of three hawaiian fruits treated by x-irradiation. J. Food Qual. 25:419-433.

Bradford, M. 1976. A rapid and sensitive method for the quantitation of microgram quantities of protein utilizing the principle of protein-dye binding. Anal. Biochem. 72:248-254.

Chalker-Scott, L. and L.H. Fuchigami. 1989. The role of phenolic compounds in plant stress responses, p. 27-40. In: Paul, H.L. (ed.). Low-temperature stress physiology in crops. CRC Press, Boca Raton, FL.

El Assi, N., D.J. Huber, and J.K. Brecht. 1997. Irradiation-induced changes in tomato fruits and pericarp firmness, electrolyte efflux, and cell wall enzyme activity as influenced by ripening stage. J. Amer. Soc. Hort. Sci. 122:100-106.

Environmental Protection Agency. 2007. Ionizing radiation fact book. 8 Aug. 2010. $<$ http://www. epa.gov/radiation/docs/402-f-06-061.pdf>.

Fan, X. and K.J. Sokorai. 2002. Sensorial and chemical quality of gamma-irradiated fresh-cut 
iceberg lettuce in modified atmosphere packages. J. Food Prot. 65:1760-1765.

Fan, X. and K.J.B. Sokorai. 2005. Assessment of radiation sensitivity of fresh-cut vegetables using electrolyte leakage measurement. Postharvest Biol. Technol. 36:191-197.

Fan, X., P.M. Toivonen, K. Rajkowski, and K. Sokorail. 2003. Warm water treatment in combination with modified atmosphere packaging reduces undesirable effects of irradiation on the quality of fresh-cut iceberg lettuce. J. Agr. Food Chem. 51:1231-1236.

Farkas, J. 2006. Irradiation for better foods. Tre. Food Sci. Tech. 17:148-152.

Farkas, J., T. Saray, C. Mohacsi-Farkas, K. Horti, and E. Andrassy. 1997. Effects of low-dose gamma radiation on shelf-life and microbiological safety of pre-cut/prepared vegetables. Adv. Food Sci. 19:111-119.

Food and Drug Administration. 2009. Code of Federal Regulation. Irradiation in the production, processing and handling of food. 3 Nov. 2010. <http://www.accessdata.fda.gov/scripts/ cdrh/cfdocs/cfcfr/CFRSearch.cfm?FR=179.26>.

Garcia-Gimeno, R.M., A.M. Castillejo-Rodriguez, E. Barco-Alcalo, and G. Zurea-Cosano. 1998. Determination of packaged green asparagus shelf life. Food Microbiol. 15:191-198.

Garcia-Villanova, B., R. Galvez, and R. Garcia. 1987. Contamination of fresh vegetables during cultivation and marketing. Intl. J. Food Microbiol. 4:285-291.

Gautam, S., A. Sharma, and P. Thomas. 1998. Gamma irradiation effect on shelf-life, texture, polyphenol oxidase and microflora of mushroom (Agaricus bisporus). Intl. J. Food Sci. Nutr. 49:5-10.

Gunes, G., J.H. Hotchkriss, and C.B. Watkins. 2001. Effects of gamma irradiation on the texture of minimally processed apple slices. J. Food Sci. 66:63-67.

Hagenmaier, R. and R. Baker. 1997. Low-dose irradiation of cut iceberg lettuce in modified atmosphere packaging. J. Agr. Food Chem. 45: 2864-2868.

Han, J., L. Gomes-Feitosa, E. Castell-Perez, R.G. Moreira, and P.F. Silva. 2004. Quality of packaged romaine lettuce hearts exposed to low-dose electron beam irradiation. Lebensm.Wiss. U.-Technol. 37:705-715.

Hennion, S., C.H. Anthony, and C. Hartmann. 1992. Activities of enzymes involved in lignification during the postharvest storage of etiolated asparagus spears. Physiol. Plant. 86:474-478

Hirai, M. 1982. Accelerated sugar accumulation and ripening of Loquat fruits by exogenously applied ethylene. J. Jpn. Soc. Hort. Sci. 51:159-164.

Howard, L.R., G.H. Miller, and A.B. Wagner. 1995. Microbiological, chemical and sensory changes in irradiated Pico De Gallo. J. Food Sci. 60:461-464.

Krzesinski, W., J. Stachowiak, M. Gasecka, and M. Knaflewski. 2007. Sugar content in spears versus asparagus yielding. Vegetable Crops Res. Bull. 67:127-136.

Lamikanra, O., J.C. Chen, D. Banks, and P.A. Hunter. 2000. Biochemical and microbial changes during the storage of minimally processed cantaloupe. J. Agr. Food Chem. 48: 5955-5961.

Lister, C.E., J.E. Lancaster, and J.R.L. Walker. 1996. Phenylalanine Ammonia-lyase (PAL) activity and its relationship to anthocyanin and flavonoid levels in New Zealand grown apple cultivars. J. Amer. Soc. Hort. Sci. 121: 281-285.

Nychas, G.J.E. and C.C. Tassou. 1996. Growth/ survival of Salmonella enteritidis on fresh poultry and fish stored under vacuum or modified atmosphere. Appl. Microbiol. 23:115-119.

Olson, D. 1998. Irradiation of food. Food Technol. 52:56-62.

Oufedjikh, H., M. Mahrouz, M.J. Ammiot, and M. Lacroix. 2000. Effect of gamma-irradiation on phenolic compounds and phenylalanine ammonia-lyase activity during storage in relation to peel injury from peel of Citrus clementina hort. Ex Tanaka. J. Agr. Food Chem. 48:559-565.

Phillips, C.A. 1996. Review: Modified atmosphere packaging and its effects on the microbiological quality and safety of produce. Intl. J. Food Sci. Technol. 31:463-479.
Powers, J.R. and S.R. Drake. 2006. Effect of cut and field-holding conditions of activity of phenylalanine ammonia-lyase and texture in fresh asparagus spears. J. Food Sci. 45:509-510.

Robertson, C.B., L.S. Andrews, D.L. Marshall, P. Coggins, M.W. Schilling, R.E. Martin, and R. Collette. 2006. Effect of x-ray irradiation on reducing the risk of listeriosis in ready-to eat vacuum-packaged smoked mullet. J. Food Prot. 69:1561-1564.

Schmidt, H. 2004. Improving the microbiological quality and safety of fresh-cut tomatoes by low dose electron beam irradiation. MS thesis, Texas A\&M Univ., Austin, TX.

Shin, J.M., J. Savage, J. Harte, K. Dolan, and B. Harte. 2008. Performance comparison of modified atmosphere packaging (MAP) and vacuum skin packaging (VSP) in maintaining the quality of fresh Michigan green asparagus. International Association of Packaging Research Institute (IAPRI) Conference. 23:123127.

Simon, A., E. Gonzalez-fandos, and V. Tobar. 2004. Influence of washing and packaging on the sensory and microbiological quality of fresh peeled white asparagus. J. Food Sci. 69: 6-12.

Sothornvit, R. and P. Kiatchanapaibul. 2009. Quality and shelf-life of washed fresh-cut asparagus in modified atmosphere packaging. LWT-Food Sci. Technol. 42:1484-1490.

Vazquez, B.U., L. Carreira, C. Franco, C. Fente, A. Cepeda, and J. Barros-Valzquez. 2004. Shelf life extension of beef retail cuts subjected to an advanced vacuum skin packaging system. Eur. Food Res. Technol. 218:118-122.

Villanueva, M.J., M.D. Tenorio, M. Sagardoy, and M.D. Saco. 2005. Physical, chemical, histological and microbiological changes in fresh green asparagus (Aspargus officinalis, L.) stored in modified atmosphere packaging. Food Chem. 91:609-619.

Waldron, K.W. and R.R. Selvendran. 1990. Effect of maturation and storage on asparagus (Asparagus officinalis) cell wall composition. Physiol. Plant. 80:576-583. 